\section{Peran Hakim Pengawas Dan Pengamat Dalam Melakukan Pengawasan Atas Putusan Yang Telah Berkekuatan Hukum Tetap Bagi Pelaku Tindak Pidana (Studi di Lembaga Pemasyarakatan Kelas II A Binjai)}

\author{
Oleh: Maria Rosalina ${ }^{1}$ \\ Widya Handary ${ }^{2}$
}

\section{Abstract}

In addition to adjudicating, the judge also has other duties, namely carrying out supervision and observation of the court decisions in accordance with Article 277-283 of the Criminal Procedure Code. Superintendent and observer Judges were wise in conducting supervision and observations aimed at obtaining certainty whether the contents of the court's decision had been implemented properly, for example whether prisoners had served their sentences in the jail, did not enter and leave the jail freely, got room facilities according to their rights, were not released late and so on.

However, in its application, there are still many contents of decisions that are not implemented as determined and follow the rules that apply to the prisoners in the jail. Besides, not all of the society at large and prisoners in particular know the existence and duties of the superintendent and observer Judges.

Keywords: Superintendent and Observer Judges, Permanent Legal Verdicts, Criminal Offenders.

\section{Abstrak}

Selain mengadili,hakim juga memiliki tugas lain yaitu melaksanakan pengawasan dan pengamatan terhadap putusan pengadilan sesuai dengan Pasal 277 - 283 KUHAP. Hakim wasmat dalam melakukan pengawasan dan pengamatan bertujuan untuk memperoleh kepastian apakah isi putusan pengadilan tersebut sudah dilaksanakan dengan baik, misal apakah narapidanatelah menjalani hukumannya di lembaga pemasyarakatan, tidak keluar masuk

\footnotetext{
'Dosen Tetap Fakultas Hukum UISU, Email:nurul.rosalina@gmail.com

${ }^{2}$ Alumni Fakultas Hukum UISU
}

lembaga pemasyarakatan dengan bebas, mendapat fasilitas kamar sesuai haknya, tidak terlambat pembebasannya dan lain-lain.

Akan tetapi pada penerapannya, masih banyak isi putusan yang tidak dilaksanakan seperti yang sudah ditetapkan dan mengikuti aturan yang berlaku bagi narapidana di lembaga pemasyarakatan. Disamping itu masyarakat pada umumnya dan narapidana khususnya, tidak semua mengetahui keberadaan dan tugas hakim wasmat ini.

Kata kunci: Hakim Pengawas dan Pengamat, Putusan Berkekuatan Hukum Tetap, Pelaku Tindak Pidana.

\section{Abstract}

In addition to adjudicating, the judge also has other duties to carry out supervision and observation of court decisions in accordance with Article 277-283 of the Criminal Procedure Code. Judge wasmat in conducting supervision and observation aimed to obtain certainty whether the contents of the court's decision had been implemented properly, for example whether a prisoner has served his sentence at the correctional facility, not entering and entering the prison freely, getting room facilities according to his rights, not being released late and others.

However, in its application, there are still many contents of decisions that are not implemented as determined and follow the rules that apply to prisoners in prison. Besides that, the general public and inmates in particular, not all of them know the existence and duties of the wasmat judge.

Keyword:Supervisor and Observer Judge, Permanent Legal Verdict, Criminal Actor.

\section{PENDAHULUAN}

\section{A. Latar Belakang}

Pengadilan sebagai tempat para pencari keadilan, tidak terlepas dari keberadaan hakim yang berperan penting dalam proses peradilan tersebut. Selain mengadili, hakim juga memiliki tugas lain yaitu melaksanakan pengawasan dan pengamatan terhadap putusan pengadilan sesuai dengan Pasal 277 - 283 Kitab Undang- 
Media Komunikasi dan Informasi Hukum dan Masyarakat

undang Hukum Acara Pidana atau KUHAP.Tugas pengawasan dan pengamatan oleh hakim ini dilakukan setelah putusan pengadilan tersebut sudah berkekuatan hukum tetap, artinya putusan tersebut sudah tidak ada upaya hukum lagi dan dapat dilaksanakan. Pengertian putusan pengadilan menurut KUHAP Pasal 1 Ayat 11 adalah pernyataan hakim yang diucapkan dalam sidang pengadilan terbuka yang dapat berupa pemidanaan atau lepas dari segala tuntutan hukum. ${ }^{3}$

Hakim pengawas dan pengamat (selanjutnya disebut hakim wasmat) dalam melakukan pengawasan dan pengamatan bertujuan untuk memperoleh kepastian bahwa putusan pengadilan tersebut dilaksanakan dengan baik sebagaimana yang sudah ditetapkan. Pengawasan dan pengamatan yang dilaksanakan oleh hakim terhadap narapidana yang berada di lembaga pemasyarakatan ini merupakan tugas khusus yang diberikan oleh ketua pengadilan kepada hakim wasmat. Ketua pengadilan menunjuk hakim yang ditugaskan sebagai hakim wasmat untuk menjalankan tugasnya tersebut.

Pengawasan yang dilakukan oleh hakim wasmat tidak dilakukan secara fisik tetapi dilakukan secara administratif. Hakim wasmat menerima laporan dan perilaku pembinaan narapidana tersebut melalui kepala lembaga pemasyarakatan. Pengawasan dan pengamatan yang dimaksud antara lain apakah narapidana yang dijatuhi hukuman oleh hakim pengadilan telah benar-benarmenjalaninya di lembaga pemasyarakatan, tidak keluar masuk lembaga pemasyarakatan dengan bebas, apakah sudah mendapatkan haknya sebagaimana mestinya,

${ }^{3}$ M.Karjadi dan R.Soesilo, Kitab UndangUndang Hukum Acara Pidana, Politeia, Bogor, 1997 , h. 4 dan tidak mendapatkan fasilitas mewah atau istimewa, apakah narapidana sudah menjalani masa hukumannya sesuai dengan apa yang diputuskan hakim, apakah kamar dihuni sudah sesuai dengan ketentuan yang ditetapkan dan sebagainya.Selanjutnya hasil pengawasan dan pengamatan yang dilakukan oleh hakim pengawas dan pengamat tersebut dilaporkan kepada ketua pengadilan.

Akan tetapi pada penerapannya, masih banyak isi putusan yang tidak dilaksanakan seperti isi putusan yang sudah ditetapkan tersebut, dan mengikuti aturan yang berlaku bagi narapidana di lembaga pemasyarakatan.Disamping itu masyarakat pada umumnya dan narapidana khususnya, tidak semua mengetahui keberadaan dan tugas hakim wasmat ini.

Dalam penerapannya, terdapat beberapa kasus tentang narapidana yang mendapatkan perlakuan istimewa atau khusus dan fasilitas khusus pada saat mereka menjalankan hukumandi lembaga pemasyarakatan, seperti Gusrin Najamuddin yang mendapatkan fasilitas mewah di ruangan sel nomor 38 di Lembaga Pemasyarakatan Sukamiskin. Ruangan tersebut dihuni oleh bekas Gubernur Bengkulu, Agusrin Najamuddin, yang berukuran 2,5 meter $\times 4$ meter, dilengkapi tempattidur, tape, meja kerja, alat masak dan rak buku. Kemudian kasus Artalyta Suryani alias Ayin, yang mendapatkan fasilitas kamar mewah di Rutan Kelas II A Pondok Bambu, Jakarta Timur, Gayus Tambunan terdakwa kasus mafia pajak yang bebas keluar masuk dari Rutan Mako Brimob, Kelapa Dua dan lain-lain. ${ }^{4}$ Menurut wakil ketua Komisi Pemberantasan Korupsi (KPK) Laode M Syarif mengungkapkan, tarif untuk mendapatkan

${ }^{4}$ Kasus Suap Di Penjara, Dari Fasilitas Wah, Hingga Izin Bepergian, tersedia pada https://nasional.kompas.com, diakses pada 28 Juli 2019. 
Media Komunikasi dan Informasi Hukum dan Masyarakat

fasilitas mewah dalam sel narapidana di Lapas Sukamiskin, Bandung, Jawa Barat itu sekitar Rp 200 juta (dua ratus juta rupiah) sampai dengan Rp 500 juta (lima ratus juta rupiah). ${ }^{5}$

Hal yang serupa juga terjadi di Lembaga Pemasyarakatan Kelas II A Binjai, dimana narapidana tidak mendapatkan haknya secara layak, yaitu adanyakelebihan kapasitas narapidana yang berada di lembaga pemasyarakatan tersebut, terlambatnya pembebasan narapidana dan banyak narapidana yang tidak mengetahui tentang keberadaan dan tugas hakim wasmat tersebut

\section{B. Perumusan Masalah}

Adapun yang menjadi permasalahan dalam penelitian ini adalah:

1. Bagaimana pengaturan hukum tentang hakim pengawas dan pengamat dalam melaksanakan tugasnya?

2. Bagaimana peran hakim pengawas dan pengamat atas pelaksanaan pengawasan dan pengamatan pada Lembaga Pemasyarakatan Kelas II A Binjai?

3. Bagaimana hambatan serta upaya yang dihadapi oleh hakim pengawas dan pengamat dalam melakukan pengawasan dan pengamatan di Lembaga Pemasyarakatan Kelas II A Binjai?

\section{Metode Penelitian}

Objek dalam penelitian ini ialah peran hakim wasmat dalam melakukan pengawasan atas putusan yang telah berkekuatan hukum tetap bagi pelaku tindak pidana. Adapun lokasi penelitian ini adalah di Lembaga Pemasyarakatan Kelas II A Binjai Jl. Jenderal

${ }_{5}$ (Lima) Kasus Fasilitas Mewah di Dalam Penjara tersedia padahttps://nasional.kompas.comdiakses pada tanggal 02 Februari 2019.
Gatot Subroto No.72, Limau Mungkur, Binjai, Sumatera Utara.Penelitian ini bersifat deskriptif yaitu berusaha mendeskripsikan suatu gejala, peristiwa, kejadian yang terjadi saat sekarang, dan memusatkan perhatian pada masalah aktual sebagaimana adanya saat penelitian berlangsung. ${ }^{6}$ Metode pendekatan yang dipakai adalah pendekatan yuridis normatif yaitu dilakukan melalui telaah tinjauan pustaka dengan cara mempelajari bahan-bahan hukum yang relevan dengan permasalahan yang ditelitidan pendekatan yuridis empiris yaitu dilakukan dengan melihat kenyataan terhadapperan hakim wasmat dalam melakukan pengawasan atas putusan yang telah berkekuatan hukum tetap bagi pelaku tindak pidanadi Lembaga Pemasyarakatan Kelas II A Binjai.

Data yang digunakan adalah pertama data primer yang diperoleh dari hasil wawancara kepada responden yaituhakim wasmat, kepala lembaga pemasyarakatan, kepala seksi bimbingan dan anak didikserta narapidana pada Lembaga Pemasyarakatan Kelas II A Binjai, dan kedua data sekunder diambil dari kepustakaankepustakaan hukum, dokumen-dokumen yang berkaitan dengan hakim wasmat yang terdiri dari bahan hukum primer, bahan hukum sekunder, dan bahan hukum tersier.

\section{HASIL DAN PENELITIAN}

\section{1) Pengaturan hukum tentang hakim pengawas dan pengamat dalam melaksanakan tugasnya.}

Hakim wasmat dalam melaksanakan tugasnya harus sesuai berdasarkan aturan hukum yang ada. Peraturan hukum yang

\footnotetext{
${ }^{6} J u l i a n s y a h$ Noor,Metode Penelitian:Skripsi, Tesis, Disertasi \& Karya IImiah, Kencana, Jakarta, 2011, h. 34
} 
Media Komunikasi dan Informasi Hukum dan Masyarakat

menjadi dasar tentang hakim pengawas dan pengamat terdapat pada KUHAP Pasal 277 sampai Pasal 283, Surat Edaran Mahkamah Agung No. 7 Tahun 1985 Tentang Petunjuk Pelaksanaan Tugas Hakim Pengawas dan Pengamat (selanjutnya disebut Sema No.7 Tahun 1985)serta Undang-undang No. 48 Tahun 2009 Tentang Kekuasaan Kehakiman, Pasal 55 Ayat (1) dan (2). ${ }^{7}$

Pasal 55 Ayat (1) UU Kekuasaan Kehakiman tersebutmenyebutkan ketua pengadilan wajib mengawasi pelaksanaan putusan pengadilan yang telah memperoleh kekuatan hukum tetap. Artinya ketua pengadilan memiliki hak dan kewajiban untuk mengawasi, bagaimana putusan yang sudah ditetapkan tersebut di jalankan. Pada dasarnya tugas ketua pengadilan cukup berat oleh karena itu diperlukan suatu lembaga khusus untuk menjalankan pengawasan dan pengamatan terhadap narapidana yang sudah berada di lembaga pemasyarakatan. Untuk melaksanakan pengawasan dan pengamatan terhadap isi putusan, bagaimana putusan itu dijalankan oleh para narapidana di lembaga pemasyarakatan tersebut, ketua pengadilan menetapkan hakim wasmat. Selanjutnya juga berdasarkan Undangundang No. 8 Tahun 1981 Tentang KUHAP Bab $\mathrm{XX}$ tentang pengawasan dan pengamatan pelaksanaan putusan pengadilan tersebut, ditentukan harus adanya hakim yang bertugas khusus untuk membantu ketua pengadilan melaksanakan pengawasan dan pengamatan terhadap putusan yang sudah berkekuatan hukum tetap.

Berdasarkan hasil wawancara, responden berpendapat bahwa perlu dibuat undang-

\footnotetext{
${ }^{7}$ Hasil wawancara dengan Nur Ervianti Hakim Pratama Utama, Hakim Wasmat pada Pengadilan Negeri Kelas I B Binjai, tanggal 10 April 2019.
}

undang tersendiri untuk mengatur tentang hakim pengawas dan pengamat, agar hakim wasmat dapat menjalankan tugasnya dengan baik. Sebab didalam undang -undang tidak terdapat aturan yang mengatur secara jelas tentang tugas, fungsi, hak, dan wewenang hakim wasmat. Dengan adanya undang - undang tersendiri juga untuk menguatkan kedudukan hakim wasmat dalam peranan fungsi dan pelaksanaan tugasnya. ${ }^{8}$

Sema No. 7 Tahun 1985 tidak menentukan secara pasti jumlah hakim wasmat, sehinggajumlahnya diserahkan kepada ketua pengadilan negeri yang bersangkutan. Menurut Sema No. 7 Tahun 1985 hakim wasmat, dapat berjumlah lebih dari satu orang pada satu pengadilan, tergantung banyak sedikitnya jumlah narapidana yang ada dalam ruang lingkup tugas pengadilan negeri yang bersangkutan. Misalnya di suatu daerah hukum pengadilan negeri terdapat lebih dari satu lembaga pemasyarakatan atau hanya satu lembaga pemasyarakatan tetapi dengan kapasitas penampungan yang besar, maka diperlukan hakim wasmat lebih dari satu orang. Mengingat Sema No. 7 Tahun 1985 tidak menentukan secara pasti jumlah hakim wasmat, maka jumlahnya diserahkan kepada ketua pengadilan negeri. Pasal 277 Ayat (1) KUHAP, yang berwenang menunjuk hakim wasmat adalah ketua pengadilan negeri, sehingga ia juga berwenang menentukan jumlah hakim wasmat. Kemudian menurut Pasal 55 Ayat (1) UUKekuasaan Kehakiman yang diberi kewajiban melakukan pengawasan adalah ketua pengadilan negeri, dengan demikian

\footnotetext{
${ }^{8}$ Hasil wawancara dengan Nur Ervianti Hakim Pratama Utama, Hakim Wasmat padaPengadilan Negeri Kelas I B Binjai, tanggal 10 April 2019.
} 
Media Komunikasi dan Informasi Hukum dan Masyarakat

keberadaan hakim wasmat adalah untuk membantu ketua pengadilan negeri.

Dalam Sema No.7 Tahun 1985 terdapat tugas-tugas apa saja yang harus dilakukan oleh hakim wasmat, tetapi tidak ada aturan yang mengatur secara mendalam tentang apa saja peran dan fungsi hakim wasmat, apa saja wewenang dari hakim wasmat dan apa sanksi yang diberikan kepada hakim wasmat apabila hakim wasmat tidak menjalankan tugas sebagaimana mestinya. Tidak adanya undangundang tersendiri yang mengatur tentang hakim wasmat ini secara lengkap, juga mempengaruhi kedudukan hakim wasmat ini dalam menjalankan tugasnya. Disamping itu keberadaan hakim wasmat ini,kenyataannya masih dianggap asing dan tidak banyak yang mengetahui adanya hakim wasmat ini.

Keberadaan hakim wasmat ini juga ditujukan untuk mengendalikan pelaksanaan putusan pengadilan yang dieksekusi jaksa dan pelaksanaannya dalam lembaga pemasyarakatan, apakah dalam pelaksanaan putusan itu terjadi penindasan terhadap hak-hak narapidana, akibat tindakan petugas yang bersifat menderitakan dan merendahkan martabat manusia.

Dengan adanya pengawasan dan pengamatandari hakim terhadap pelaksanaan putusan yang telah berkekuatan hukum tetap, maka diharapkan lebih mendekatkan pengadilan dengan kejaksaan, juga terhadap lembaga pemasyarakatan dalam rangkaian proses pidana dan memberi tugas pada hakim untuk tidak berakhir pada saat putusan pengadilan dijatuhkan olehnya. ${ }^{9}$

${ }^{9}$ Hendrastanto Yudowidagdo, AnangSuryanata Kesuma, Sution Usman Adji, Agus Ismunarto,

Kapita Selekta Hukum Acara Pidana Di Indonesia, PT. Bina Aksara, Jakarta, 1987, h. 271
Dengan adanya pengawasan dan pengamatan yang dilakukan oleh hakim wasmat tersebut, maka mereka akan mengetahui hasil yang baik maupun buruk dari suatu putusan pengadilan yang sudah ditetapkan.Hakim wasmat dalam tugasnya dapat menjamin bahwa putusan yang dijatuhkan pengadilan negeri dilaksanakan sebagaimana mestinya, hal ini sesuai dengan bunyi Pasal 280 Ayat (1) KUHAP. Karena pemidanaan bukanlah untuk menderitakan atau tindakan balas dendam atas perbuatan narapidana,melainkan untuk pembinaan narapidana baik secara psikis maupun pisik agar dapat atau siap kembali kedalam lingkungan masyarakat sebagai manusia seutuhnya dan taat pada hukum ${ }^{10}$.

2) Peran hakim pengawas dan pengamat atas pelaksanaan pengawasan dan pengamatan pada Lembaga Pemasyarakatan Kelas II A Binjai.

Sebagimana telah disebutkan, Pasal 280 KUHAP yang menguraikan hakim wasmat mengadakan pengawasan dan pengamatan untuk mengetahui bahwa keputusan pengadilan dilaksanakan sebagaimana mestinya. Mengenai pengamatan ini, hakim agung Purwoto $\mathrm{S}$. Gandasubrata menjelaskan pengamatan dititikberatkan pada kemanfaatan dan ketepatan pidana dalam rangka menentukan atau menemukan sentencing policy yang baik. ${ }^{11}$

Hakim wasmat ini ditunjuk selama 2 (dua) tahun, khusus untuk mengawasi dan mengamati narapidana selama waktu

${ }^{10}$ Hakim Pegawas dan Pengamat tersedia di https://jabar.kemenkumham.go.id, diakses pada tanggal 26 April2019.

${ }^{11}$ Boy Mardjono Reksodiputro, Hak Asasi Manusia dalam Sistem Peradilan Pidana, Pusat Pelayanan Keadilan dan Pengabdian Hukum Universitas Indonesia, Jakarta, 1997, h. 62 
Media Komunikasi dan Informasi Hukum dan Masyarakat

narapidana tersebut menjalani hukumannya dalam lembaga pemasyarakatan, sebagai pelaksana dari putusan hakim pengadilan negeri tersebut, tentang kelakuan para narapidana dan para petugas yang mengasuh lembaga pemasyarakatan terhadap diri narapidana tersebut. $^{12}$

Peranan hakim wasmat dilaksanakan terhadap putusan pengadilan yang menjatuhkan pidana perampasan kemerdekaan kepada narapidana. Tujuan pidana perampasan kemerdekaan tersebut antara lain yaitu penjara sebagai sarana maka terdapat pengamanan terpidana dan memberikan kesempatan-kesempatan kepada narapidana untuk merehabilitas. ${ }^{13}$

Dalam melaksanakan tugas pengawasan itu hendaknya hakim wasmat menitik-beratkan pengawasannya antara lain pada apakah jaksa telah menyerahkan terpidana kepada lembaga pemasyarakatan tepat pada waktunya, apakah masa pidana yang dijatuhkan oleh pengadilan benar-benar dilaksanakan secara nyata dalam praktek dan apakah pembinaan terhadap narapidana benar-benar manusiawi sesuai dengan prinsip-prinsip pemasyarakatan, yaitu antara lain apakah narapidana memperoleh hak-haknya sepanjang persyaratan persyaratan prosedural sesuai sistem pemasyarakatan telah terpenuhi (misalnya pemberian asimilasi, remisi, cuti, lepas bersyarat/integrasi dan lain-lain), mengumpulkan data-data tentang perilaku narapidana, yang dikategorikan berdasarakan jenis-jenis tindak pidananya (misalnya pembunuhan, perkosaan, dan sebagainya),mengadakan evaluasi mengenai hubungan antara perilaku narapidana

${ }^{12}$ Hendrastanto Yudowidagdo, dkk, Loc.Cit.

${ }^{13}$ Petrus Irwan Panjaitan, Pandapotan Simorangkir, Lembaga Pemasyarakatan Dalam Persektif Sistem Peradilan Pidana, Pustaka Sinar Harapan, Jakarta, 1995, h.22 tersebut dengan pidana yang dijatuhkan, apakah lamanya pidana yang dijatuhkan terhadap narapidana dengan perilaku tertentu sudah tepat (dalam arti cukup) untuk melakukan pembinaan terhadap dirinya sehingga pada waktu dilepaskan nanti, narapidana tersebut sudah dapat menjadi anggota masyarakat yang baik dan taat pada hukum.Data-data yang telah terkumpul dari tugas-tugas yang telah diperinci tersebut diatas dilaporkan secara tertulis oleh hakim wasmat kepada ketua pengadilan negeri paling sedikit 3 (tiga) bulan sekali, dengan tembusan kepada Kepala Lembaga Pemasyarakatan, Kepala Kejaksaan Negeri, Ketua Pengadilan Tinggi, Kepala Kantor Wilayah Departemen Kehakiman, Kepala Kejaksaan Tinggi, Ketua Mahkamah Agung, Menteri Kehakiman dan Jaksa Agung Republik Inodnesia.Selanjutnya Ketua Pengadilan Negeri meneruskan laporan tersebut kepada hakimyang telah memutus perkara narapidana yang bersangkutan, agar hakim tersebutmengetahui hal-hal yang berkaitan dengan putusannya. Berdasarkan hasil wawancara dengan responden, salah satu dari tugas hakim wasmat tersebut adalahchicking on the spot (melakukan kunjungan) ke lembaga pemasyarakatan. Sebagaimana disebutkan oleh Sema No. 7 Tahun 1985, hakim wasmat mempunyai kewajiban melakukan kunjungan langsung ke lembaga pemasyarakatan paling sedikit 3 (tiga) bulan sekali, untuk memeriksa kebenaran berita acara pelaksanaan putusan pengadilan yang ditandatangani oleh jaksa, lembaga pemasyarakatan dan terpidana. Menurut pendapat responden, seharusnya hakim wasmat dalam melakukan checking on the spottidak hanya 3 (tiga) bulan sekali, mengingat banyak hal yang harus diketahui lebih mendalam tentang narapidana yang 
Media Komunikasi dan Informasi Hukum dan Masyarakat

beradadilembaga pemasyarakatan, disamping itu jumlah narapidana yang ada di lembaga pemasyarakatanpada umumnya melebihi jumlah yang ditetapkan. ${ }^{14}$ dan khusus di Lembaga Pemasyarakatan Kelas II A Binjai jumlah narapidana sampai per April 2019, mencapai 1859 (seribu delapan ratus lima puluh sembilan) orang, dansudah melebihi kapasitas yang seharusnya hanya 858 orang. ${ }^{15}$

Khusus di Lembaga Pemasyarakatan kelas II A Binjai, menurut responden Maju Amintas Siburian sebagai Kepala Lembaga Pemasyarakatan kelas II A Binjai, hakim wasmat tersebut melakukanchicking on the spot (melakukan kunjungan) ke lembaga pemasyarakatan sebanyak 1(satu) bulan sekali. $^{16}$

Berdasarkan hasil angket yang diberikan kepada 10 (sepuluh) orang responden narapidana yang berada di Lembaga Pemasyarakatan Kelas II A Binjai, hanya 2 (dua) orang responden narapidana yang mengetahui adanya hakim wasmat, dan dari 2 (dua) orang responden narapidana ini, hanya 1 (satu) orang narapidana yang pernah dikunjungi oleh hakim wasmat.

Ketidaktahuan responden narapidana terhadap keberadaan hakim wasmat ini, berdasarkan wawancara kepada responden kasubsi registrasi di Lembaga Pemasyarakatan Kelas II A Binjai, karena kurangnya sosialisasi

\footnotetext{
${ }^{14}$ Hasil wawancara dengan Maju Amintas Siburian, selaku Kepala Lembaga Pemasyarakatan Kelas II A Binjai, tanggal 12 April 2019.
}

15 Hasil wawancara dengan Dekki Susanto, selaku Kepala Seksi Bimbingan dan Anak Didik di Lembaga Pemasyarakatan Kelas II A Binjai, tanggal 12 April 2019.

${ }^{16} \mathrm{Hasil}$ wawancara dengan Maju Amintas Siburian, Kepala Lembaga Pemasyarakatan Kelas II A Binjai, tanggal 12 April 2019. kepada narapidana tentang hakim wasmat, minimnya kunjungan hakim wasmat dan juga mengingat ada beberapa narapidana yang masih baru menjalani masa hukumannya di Lembaga Pemasyarakatanll A Binjai. ${ }^{17}$

Adapun peran pengawasan dan pengamatan oleh hakim di Lembaga Pemasyarakatanll A Binjaimeliputi bagaimana masa hukuman itu dijalankan, bagaimana masa pembebasannya,bagaimana pelayanan lapas terhadap narapidana, memperhatikan fasilitasfasilitas yang ada di lembaga pemasyarakatan misal bagaimana keadaan dapur,bagaimana keadaan kamar,bagaimana makanan yang didapat para narapidana,melakukan pengecekan keberadaan narapidana, bagaimana proses pembinaan yang diberikan,mengadakan peninjauan terhadap keadaan, suasana dan kegiatan-kegiatan yang berlangsung didalam lingkungan temboktembok lembaga, khususnya untuk menilai apakah keadaan lembaga pemasyarakatan tersebut sudah memenuhi pengertian bahwa pemidanaan tidak dimaksudkan untuk menderitakan dan tidak diperkenankan untuk merendahkan martabat manusia, serta mengamati bagaimana perilaku narapidana sehubungan dengan pidana yang dijatuhkan kepadanya dan lain-lain.

Dalam pelaksanaan peran pengawasan dan pengamatan yang dilakukan oleh hakim di Lembaga Pemasyarakatanll A Binjai ini, masalah yang paling sering dikeluhkan antara lain lebihnya jumlah narapidana yang terdapat pada lembaga pemasyarakatan, dan keterlambatan masa pembebasan narapidana.

17 Hasil wawancara dengan Edward $P$. Situmorang, selaku Kasubsi Registrasi LembagaPemasyarakatan Kelas II A Binjai, tanggal 12 April 2019. 
Media Komunikasi dan Informasi Hukum dan Masyarakat

Keterlambatan proses pembebasan narapidana ini menurut responden dikarenakan lamanya proses registrasi yang dilakukan, sehingga mengakibatkan masa tahanan narapidana tersebut melewati putusan yang sudah ditetapkan oleh pengadilan. Sebenarnya hal ini sudah dicoba untuk diminimalisirkan oleh pihak pengadilan, tetapi masalah registrasi tentang narapidana tersebut bukan wewenang pengadilan sepenuhnya melainkan juga wewenang kejaksaan. ${ }^{18}$

\section{3) Hambatan dan upaya yang dihadapi oleh} hakim pengawas dan pengamat dalam melakukan pengawasan dan pengamatan di Lembaga Pemasyarakatan Kelas II A Binjai

Adapun hambatan dan upaya yang dihadapi oleh hakim pengawas dan pengamat dalam melakukan pengawasan dan pengamatan di Lembaga Pemasyarakatan Kelas II A Binjai, antara lain :

1. Aturan hukum yang kurang tegas tentang hakim wasmat.

Ruang lingkup hakim wasmat dalam tugasnya adalah mengawasi narapidana yang ada di lembaga pemasyarakatan di wilayah hukum pengadilan negeri tempat hakim bertugas sehari-harinya. Akan tetapi tugas hakim wasmat ini tidak berjalan secara maksimal, hal ini karena tidak diikuti dengan sejumlah ketentuan yang mengaturnya secara khusus dan tersendiri, sehingga hakim wasmat dalam melaksanakan tugasnya apabila masuk kedalam instasi lain di luar lembaga pemasyarakatan dapat dianggap mencampuri

\footnotetext{
${ }^{18} \mathrm{Hasil}$ wawancara dengan Nur Ervianti Hakim Pratama Utama, Hakim Wasmat padaPengadilan Negeri Kelas I B Binjai, tanggal 10 April 2019.
}

secara formal wewenang instansi lain tersebut. Hakim wasmat dalam melaksanakan tugasnya berpedoman kepada Sema Nomor 7 Tahun 1985, yang berlakunya untuk internal lembaga mahkamah agung dan peradilan dibawahnya, dan Sema tersebut tidak termasuk dalam hierarki peraturan perundang-undangan, sehingga tidak mengikat pihak lain atau hanya berlaku secara internal Mahkamah Agung saja. Dengan demikian sebagai penyelesaiannya agar hakim wasmat dapat bekerja serta melakukan pengawasan dan pengamatan dengan baik maka perlu dibuat suatu aturan perundangan yang khusus mengatur secara rinci tentang peran, fungsi, wewenang, anggaran, jumlah hakim wasmat dan sebagainya.

\section{Kurangnya sosialisasi mengenai hakim} wasmat.

Berdasarkan hasil penelitian banyak narapidana maupun masyarakat umum yang tidak mengetahui tentang keberadaan hakim wasmat, tidak mengetahui tentang peran, tugas, dan fungsi dari hakim wasmat. Hal ini disebabkan karena kurangnya sosialisasi mengenai hakim wasmat di kalangan narapidana ataupun masyarakat umum. Seharusnya keberadaan hakim pengawas dan pengamat ini diketahui oleh semua kalangan, mengingat salah satu tugas dan fungsi dari hakim wasmat ialah melindungi hak-hak narapidana selama menjalani masa tahanan di lembaga pemasyarakatan. Dengan demikian diperlukan sosialisasi yang maksimal misalnya melalui diskusi ilmiah seminar, focus group discussion, penyuluhan hukum, audiensi dan lain-lain.

\section{Jarak yang jauh dari pengadilan negeri ke lembaga pemasyarakatan.}


Media Komunikasi dan Informasi Hukum dan Masyarakat

Salah satu tugas hakim wasmat ialah melakukan checking on the spot (kunjungan langsung) ke lembaga pemasyarakatan untuk melihat keadaan narapidana dan keadaan lembaga pemasyarakatan. Tidak semua lembaga pemasyarakatan letaknya berdekatan dengan Pengadilan Negeri Kelas II A Binjai ini. Ada lembaga pemasyarakatan yang letaknya jauh dari Pengadilan Negeri Kelas II A Binjai, sehingga membutuhkan waktu tempuh yang lama dan alat transportasi, sedangkan Pengadilan Negeri Kelas II A Binjai tidak ada menyediakan alat transportasi, sehingga harus memakai kenderaan pribadi dari hakim wasmat yang bersangkutan. Hal ini tentunya akan menjadi masalah, bagaimana jika hakim wasmat tersebut tidak memiliki atau tidak membawa kenderaannya? Hal ini tentunya akan menghambat atau memperlambat pelaksanaan tugas hakim wasmat. Dengan demikian, untuk mengatasi persoalan alat transportasi tersebut, pengadilan negeri harus ada menyediakan alat transportasi.

\section{Berita acara eksekusi yang lambat dari jaksa penuntut umum}

Berita acara eksekusi dari jaksa penuntut umum terlambat bahkan kadang tidak dikirim sehingga menjadi kendala ketika akan mewawancarai tahanan yang sudah menjadi narapidana. Agar dapat mewawancarai narapidana, hakim wasmat hanya berdasarkankepada catatan para hakim atau majelis. Tidak adanya berita acara eksekusi tersebut juga menyebabkan sulitnya pengisian register hakim wasmat. Dengan demikian sangat diharapkan penuntut umum dapat bekerja lebih professional dan membangun koordinasi dengan pengadilan negeri, sehingga berita acara eksekusi tersebut tidak terlambat bahkan jangan sampai tidak dikirimkan ke pengadilan negeri bersangkutan, untuk diteruskan kepada hakim wasmat.

\section{Jumlah hakim yang terbatas.}

Keberadaan hakim yang sangat terbatas di suatu wilayah kabupaten/kota akan sangat membebani tugas pokok hakim untuk mengadili perkara, karena tidak sebandingnya jumlah hakim dengan perkara yang harus disidangkan. Melaksanakan tugas pokok sebagai hakim saja sudah menyibukkan para hakim, apalagi jika diberi tugas tambahan lain yaitu menjadi hakim wasmat. Untuk itu diperlukan penambahan jumlah hakim yang sebanding dengan jumlah perkara yang diadili, bahkan jika perlu pengadilan negeri dapat mengadakan hakim yang tugasnya khusus untuk menjadi pengawas dan pengamat.

\section{Benturan antara instasi yang terkait.}

Benturan antara instansi terkait, menyangkut kondisi birokrasi pemerintahan khususnya dibidang penegakan hukuman. Untuk menjalankan tugasnya sebagai hakim wasmat maka ada pihak atau intansi pemerintah lain seperti kejaksaan yang juga harus terlibat dalam pelaksanaan tugas tersebut. Misalnya, dengan terlambatnya berita acara yang disampaikan dari pihak kejaksaan kepada hakim wasmat, maka hal tersebut dengan sendirinya juga menghambat tugas hakim wasmat untuk melakukan pengawasan dan pengamatan terhadap narapidana yang akan menjalani hukumannya maupun yang sudah bebas, guna menghindari perbuatan yang sama (residivis).

Koordinasi merupakan hal yang sangat mudah untuk diucapkan, tetapi tidak demikian ketika hal tersebut diimplementasikan di lapangan.Benturan antarinstansi dapat terjadi karena adanya egoisme dari setiap instansi. Untuk mengatasi hal ini diperlukan adanya saling pengertian, menghormati, sehingga dapat 
Media Komunikasi dan Informasi Hukum dan Masyarakat

memberikan kerjasama dan koordinasi yang baik.

\section{Anggaran (dana) khusus untuk hakim wasmat}

Tidak adanya anggaran atau dana khusus untuk hakim wasmat merupakan salah satu faktor yang menghambat hakim wasmat melakukan tugasnya. Untuk menempuh jarak yang jauh dari pengadilan negeri ke lembaga pemasyarakatan, hakim harus mengeluarkan dana pribadi. Tentunya hal ini tidaklah sesuai dengan prinsip keadilan dan hak asasi manusia, sehingga diperlukan kebijakan yang tegas untuk mengatur tentang anggaran hakim wasmat ini.

\section{Beban tugas}

Selain hakim wasmat bertugas sebagai pengawas dan pengamat, hakim wasmat juga menjabat sebagai hakim pengadilan negeri yang mengadili, memeriksa dan memutus perkara, yang merupakan tugas pokokn.Oleh karena tugas pengawasan dan pengamatan di lembaga pemasyarakatan bukan merupakan tugas pokok seorang hakim, namun hanya sebagai tugas tambahan yang diberi oleh ketua pengadilan negeri, maka dalam pelaksanaan tugasnya hakim wasmat kurang optimal bahkan tidak ada waktu sama sekali. Disamping itu, pelaksanaan tugas yang tidak optimal oleh hakim wasmat juga disebabkan karena tidak adanya aturan atau undang-undang khusus yang mengatur lebih jelas tentang apa saja tugas serta peran hakim wasmat dan apa sanksi yang diberikan kepada hakim wasmat apabila tidak menjalani tugasnya dengan benar. Dengan demikian perlu dibuat suatu peraturan beserta sanksi yang lebih jelas dan terperinci tentang hakim wasmat.

Sistem pembinaan narapidana di lembaga pemasyarakatan merupakan hal yang sangat berpengaruh bagi narapidana tersebut untuk berkelakuan lebih baik setelah selesai menjalani hukumannya di lembaga pemasyarakatan dan memberikan efek jera untuk tidak mengulang perbuatan tindak pidana. Pada umumnya masyarakat enggan menerima orang yang pernah menjadi narapidana, mengucilkan, menjauhi, tidak memperdulikan, bahkan adanya sikap penolakanyang berlebihlebihan dari masyarakat terhadap bekas narapidana tersebut.Sikapmasyarakat yang tidak menerima dan mengucilkan ini dapat mendorong kembali tindakan agresif dalam diri bekas narapidana, sehingga tidak menutup kemungkinan diulanginya tindakan kekerasan dan perbuatan melanggar hukum oleh bekas narapidana tersebut. Dengan demikian faktor dari luar lembaga pemasyarakatan, juga sangat menentukan untuk menciptakan terwujudnya sistem pembinaan narapidana dan perlu adanya pengetahuan serta kesadaran masyarakat dalam ikut serta dalam pengamatan dan pengawasan .

Menurut responden upaya yang dapat dilakukan untuk mengatasi hambatan hakim wasmat dalam melaksanakan tugasnya adalah membuat anggaran khusus untuk hakim wasmat, agar segala sesuatu aspek seperti akomodasi bisa terpenuhi demi meringgankan langkah hakim wasmat yang bertugas, serta supaya pemerintah membuat undang-undang tersendiri tentang hakim wasmat agar kedudukan hakim wasmat lebih kuat dan mengoptimalkan kinerja hakim pengawas dan pengamat. ${ }^{19}$

\footnotetext{
${ }^{19}$ Hasil wawancara dengan Nur Ervianti Hakim Pratama Utama, Hakim Wasmat padaPengadilan Negeri Kelas I B Binjai, tanggal 10 April 2019.
} 
Media Komunikasi dan Informasi Hukum dan Masyarakat

\section{KESIMPULAN}

1. Pengaturan hukum tentang hakim wasmat terdapat pada a.Undang-undang No. 48 Tahun 2009 Tentang Kekuasaan Kehakiman, Pasal 55 Ayat (1).

b.Kitab Undang-undang Hukum Acara Pidana Pasal 277-283.

c.Surat Edaran Mahkamah Agung No. 7 Tahun 1985 Tentang Petunjuk Pelaksanaan Tugas Hakim Pengawas dan Pengamat.

2. Peran hakim wasmat terhadap pelaksanaan pengawasan dan pengamatan di Lembaga Pemasyarakatan Binjai Kelas II A Binjai belum optimal berdasarkan hasil penelitian, banyak narapidana yang tidak mengetahui tentang hakim wasmat. Beberapa hak narapidana belum terpenuhi seperti penghuni kamar yang melebihi kapasitas dan terlambatnya proses pembebasan narapidana.

3. Hambatan yang dihadapi oleh hakim wasmat di Lembaga Pemasyarakatan Binjai Kelas II A yaitu aturan hukum yang kurang tegas tentang hakim wasmat, kurangnya sosialisasi mengenai hakim wasmat, jarak yang jauh dari pengadilan negeri ke lembaga pemasyarakatan, berita acara eksekusi yang lambat dari jaksa penuntut umum, jumlah hakim yang terbatas, benturan antara instasi yang terkait, anggaran (dana) khusus untuk hakim wasmat, dan adanya beban tugas

\section{Daftar Bacaan}

\section{A. Buku}

Boy Mardjono Reksodiputro, Hak Asasi Manusia dalam Sistem Peradilan Pidana, Pusat Pelayanan Keadilan dan Pengabdian Hukum Universitas Indonesia, Jakarta, 1997.

Hendrastanto Yudowidagdo, Anang Suryanata Kesuma, Sution Usman Adji, Agus Ismunarto, Kapita Selekta Hukum Acara Pidana Di Indonesia, PT. Bina Aksara, Jakarta, 1987.

Juliansyah Noor,

Metode Penelitian:Skripsi,Tesis, Disertasi \& Karya IImiah, Kencana, Jakarta, 2011.

M.Karjadi dan R.Soesilo, Kitab UndangUndang Hukum Acara Pidana, Politeia, Bogor, 1997.

Petrus Irwan Panjaitan, Pandapotan Simorangkir, Lembaga Pemasyarakatan Dalam Persektif Sistem Peradilan Pidana, Pustaka Sinar Harapan, Jakarta, 1995.

\section{B. Peraturan}

Undang-undang Nomor 48 Tahun 2009 Tentang Kekuasaan Kehakiman.

Kitab Undang-undang Hukum Acara Pidana.

Surat Edaran Mahkamah Agung Nomor 7 Tahun 1985 Tentang Petunjuk Pelaksanaan Tugas Hakim Pengawas dan Pengamat.

\section{Internet}

Kasus Suap Di Penjara, Dari Fasilitas Wah, Hingga Izin Bepergian, tersedia pada https://nasional.kompas.com, diakses pada 28 Juli 2019.

5 (Lima) Kasus Fasilitas Mewah di Dalam Penjara tersedia pada https://nasional.kompas.comdiakses pada tanggal 02 Februari 2019.

Hakim Pegawas dan Pengamat tersedia di https://jabar.kemenkumham.go.id,di akses pada tanggal 26 April 2019 